\title{
Urgences
}

\section{Liminaire I (entrée)}

\section{André Gervais et Renald Bérubé}

Numéro 15, octobre 1986

Épigraphiques

URI : https://id.erudit.org/iderudit/025274ar

DOI : https://doi.org/10.7202/025274ar

Aller au sommaire du numéro

Éditeur(s)

Urgences

ISSN

0226-9554 (imprimé)

1927-3924 (numérique)

Découvrir la revue

Citer ce document

Gervais, A. \& Bérubé, R. (1986). Liminaire I (entrée). Urgences, (15), 5-5.

https://doi.org/10.7202/025274ar

Ce document est protégé par la loi sur le droit d'auteur. L’utilisation des services d'Érudit (y compris la reproduction) est assujettie à sa politique d'utilisation que vous pouvez consulter en ligne.

https://apropos.erudit.org/fr/usagers/politique-dutilisation/
Cet article est diffusé et préservé par Érudit.

Érudit est un consortium interuniversitaire sans but lucratif composé de l’Université de Montréal, l'Université Laval et l'Université du Québec à Montréal. Il a pour mission la promotion et la valorisation de la recherche. https://www.erudit.org/fr/ 


\section{Liminaire I (entrēe)}

Epigraphe, n.f. (1694; gr. epigraphê "inscription"). [...] $2^{\circ}$ Courte citation qu'un auteur met en tête d'un livre, d'un chapitre, pour en indiquer l'esprit (Cf. Exergue).

Petit Robert I

N'arrive-t-il pas à chacun-e d'entre nous, un jour ou l'autre, la chose suivante: en cours d'écriture, on lit ceci ou cela - poème, roman, essai ou journal, magazine, par exemple - et l'on tombe, littéralement, sur une phrase qui sonne juste, qui amorcerait, résumerait, contesterait, pointerait si bien ce qu' on est, justement, en train de construire et d'ajuster. Et on inscrit, on épingle sur ce qu'on fait, au haut, ce diapason inespéré, ce focus intéressé.

La proposition au départ de ce numéro va exactement à l'encontre de ce qui vient d'être dit. Il s'agit plutôt, d'abord, de choisir, pour les mêmes raisons plastiques qu'auparavant, une épigraphe et d'en "tirer", d'en "découler", ensuite, de toute manière, tel texte.

Entendre ici Franz Kafka (Journal, 5 novembre 1911): "J'avais espéré satisfaire un peu mon amour pour elle en lui donnant mon bouquet, c'était complètement inutile. Cela n'est possible que par la littérature ou le coiit. Je n'écris pas cela parce que je l'ignorais, mais parce qu'il est peut-être bon de mettre fréquemment les avertissements par écrit." Ce que nous faisons d'entrée de jeu.

À vous, maintenant, selon telle coupe ici réunie, ce champ d'épigraphiques.

\section{A.G. / R.B.}

P.S. Nous tenons à remercier Jacquelin Marcheterre pour l'aide apportée à la préparation du numéro. 